\title{
Turizm Eğitimi Alan Önlisans Öğrencilerinin Sektöre Yönelik Meslek Algıları: Pamukkale Üniversitesi Örneği ${ }^{1}$
}

\author{
DOI: $10.26466 /$ opus.554480 \\ * \\ Ahmet Cetin $^{*}$ - Seher Ceylan** - Nuray Selma Özdipçiner*** \\ * Öğr. Gör., Pamukkale Üniversitesi, Denizli Sosyal Bilimler MYO, Denizli/ Türkiye \\ E-Posta: cetina@pau.edu.tr \\ ORCID: $\quad$ 0000-0002-0753-8175 \\ ** Dr. Öğr. Üyesi, Pamukkale Üniversitesi, Denizli Sosyal Bilimler MYO, Denizli / Türkiye \\ E-Posta: ceylans@pau.edu.tr O ORCID: 0000-0003-0968-1052 \\ *** Prof. Dr. Pamukkale Üniversitesi, Turizm Fakültesi, Denizli / Türkiye \\ E-Posta: nselma@pau.edu.tr \\ ORCID: $\quad$ 0000-0001-6968-5691
}

Öz.

Turizm, günümüzün en önemli meslek alanlarından biri olmasına rağmen, turizm eğitimi alan öğrencilerin bu mesleğe yönelik algıları farklılık göstermektedir. Turizm faaliyetleri, ülkelere kazandırdı ğı gelir ve istihdama să̆ladı̆̆ katkı açısından değerlendirildiğinde, en yüksek derecede geliri elde etmek ve müşteri memnuniyetini sağlamak açısından kalifiye eleman yetiştirmek ve bu eğitimli işgücünü turizm sektörüne kazandırmak şarttır. Literatür incelendiğinde, turizm eğitimi alan öğrencilerin turizme yönelik meslek algısı konusunda birçok çalışmaya rastlanmaktadır. Öğrenim hayatı sonunda, turizm sektöründe çalışmayı hedefleyen üniversite öğrencilerinin, mesleklerinin onlara sunduğu çalışma koşullarını, kendilerini geliştirme imkânlarını, kariyer olanaklarını nasıl algıladıkları ve sektörü nasıl gördükleri ve bu mesleğin bir parçası olmak açısından önemlidir. Bu çalışmada turizm eğitimi alan önlisans öğrencilerinin demografik verilerine göre, turizm sektörüne yönelik algılarında farklllık olup olmadığı araştırılmıştır. Bu amaç doğrultusunda, Pamukkale Üniversitesi Denizli Sosyal Bilimler Meslek Yüksekokulunda turizm eğitimi alan önlisans öğrencilerine yönelik bir anket uygulaması gerçekleştirilmiştir. Çalışma sonucunda öğrencilerin demografik özellikleri ile mesleğe yönelik algıları arasında farklılıklar tespit edilmiştir.

Anahtar Kelimeler: Turizm, Meslek Algısı, Önlisans Öğrencileri

\footnotetext{
${ }^{1}$ Bu çalışma, 2. International Symposium on Innovative Approaches in Scientific Studies (ISAS Winter 2019) de sözlü bildiri olarak sunulmuş, sonrasında genişletilerek makale haline getirilmiştir.
} 


\title{
The Occupational Perceptions of The Associate Degree Tourism Students to The Sector: Pamukkale University Case
}

\begin{abstract}
Although tourism is one of the most important occupational areas of today, the perceptions of the students who gets the tourism education differ on this profession. When the tourism activities are evaluated in terms of its contribution to income and employment, it is essential to bring this educated, trained and qualified personnel labor force to the tourism sector. When the literature is examined, there are many studies on the profession perception of the students to the tourism sector. At the end of the education, it is important the perception of the students who aim to work in the tourism sector, that the conditions offered by this profession, the opportunities to develop themselves and how they perceive their career opportunities in tourism. In this study, it has been investigated that the perception differences of tourism associate degree program students towards tourism sector according to their demographic variables. For this purpose, a questionnaire was conducted for the associate degree students who were studying tourism at Pamukkale University Denizli Vocational School of Social Sciences. As a result of the study, differences between the demographic characteristics of the students and their perceptions about the profession were determined
\end{abstract}

Keywords: Tourism, Profession Perception, Associate Degree Students 


\section{Giriş}

Turizm, günümüzde bütün ülkeler için son derece önemli bir sektördür. Yüksek ölçüde gelir sağlayan ve istihdama katkıda bulunan turizm faaliyetleri için her ülke fiziksel ve teknolojik yatırımlarda bulunmaktadır. Bu sektörden azami ölçüde kazanç elde etmek için kaliteli hizmet sunmak ve konuk memnuniyetini sağlamak gerekmektedir. Bu sebeple, sadece fiziksel anlamdaki turistik yatırımların değil, insan faktörüne yapılan yatırımların da aynı oranda geliştirilmesi gerekmektedir. Zira emek yoğun bir sektör olan turizmin en önemli bileşenlerinden biri de hizmeti üretip sunan eğitimli ve kalifiye işgücüdür. Kaliteli hizmet sunmanın ilk adımı vasıflı ve eğitimli işgücünü sektöre kazandırmaktır. Bu işgücünün yetiştirilmesi de etkili bir turizm eğitimi ile mümkündür. Ülkemizde gerek ortaöğretim gerekse yükseköğretim seviyelerinde turizm eğitimi verilmekte ve bu eğitimi alan bireylerin de turizm sektöründe hizmet vermesi beklenmektedir. Zira iyi yetişmiş ve eğitimli işgücü, turizmde hizmet kalitesinin devamlılığında çok önemli rol oynamaktadır. Sektörde özellikle kalifiye ara eleman ihtiyacının var olduğu bilinmekle birlikte, turizmde çal1şanların birçoğunun söz konusu eğitime sahip olmadığı da görülmektedir. Ne yazık ki yapılan araştırmalar, turizm eğitimi alan öğrencilerin önemli bir kısmının sektörde çalışmak istemediklerini veya turizmin d1şındaki başka alanlarda meslek edindiklerini göstermektedir. Bireylerin meslek seçimleri, gerek ekonomik fayda sağlamak gerekse toplumda meslekleri aracılığıyla bir statü elde etmek anlamında önemli bir seçimdir. Turizm eğitimi alan öğrencilerin, turizmi bir meslek olarak nasıl gördükleri, turizmin çalışma koşulları konusundaki algıları ve sektöre bakış açılarının değerlendirilmesi de bu bağlamda önemlidir.

Turizm eğitimi alan öğrencilerin mesleğe bakış açıları konusuna ilişkin literatür incelendiğinde, araştırmaların genel olarak, öğrencilerin turizm eğitimi almayı seçerken bölüm ve meslekle ilgili tercih sebepleri (Köşker ve Unur 2017, Grobelna, 2017, Baltacı vd. 2012, Çimen 2008), eğitimlerinden memnun olup olmadıkları (Baltacı vd. 2012, Üngüren ve Ehtiyar 2009), mesleğe ve turizm mesleğindeki geleceklerine yönelik bakış açıları (Baltacı vd. 2012, Üzümcü vd. 2015), turizm sektörüne yönelik genel olarak tutumları (Üngüren ve Ehtiyar 2009, Wijesundara 2015, Orhan 2015, Olcay ve Çelik 2010), meslekten beklentileri (Orhan 2015, Zubaidah vd., 
2016, Lu ve Adler, 2009, Cömert 2014, Duman vd. 2006) ve demografik faktörlere göre öğrencilerin mesleğe bakış açlarının değişip değişmediği (Baltacı vd. 2012, Olcay ve Çelik 2010, Avcı 2011, Cömert 2014, Duman vd. 2006, Sarışık 2007, Çimen 2008, Zengin ve Kırmızı 2017, Köşker Ve Unur 2017) konuları üzerinde durulduğu görülmektedir.

Turizm sektörünün çok hızlı bir şekilde büyümesi, bu sektörde ihtiyaç duyulan işgücünün miktarı ve kalitesi ile ilgili sorunları gündeme getirmektedir. Birçok hizmetin doğrudan çalışanlar tarafından verildiği turizm endüstrisinde, rekabete dayalı avantaj öncelikle turizm deneyiminin ayrılmaz bir parçası olarak algılanan insanlar (çalışanlar) aracılığıyla sağlanır (Grobelna, 2017). Araştırma bulguları, öğrencilerin, turizm sektöründe çalışmak için onları motive eden iki temel unsurun, sosyal statü ve ücret olduğunu göstermektedir (Zubaidah vd. 2016, Lu ve Adler 2009). Özellikle sosyal statünün öğrencilerin kariyer beklentilerine yönelik algılarını etkilediği ve algılanan kariyer beklentilerinin de öğrencilerin sektöre olan bağll1ıkları için önemli bir belirleyici olduğu görülmüştür (Wan vd., 2014). Ayrıca, genel olarak mesleğe olumlu bakan öğrencilerin elde edilen statü, ücret paketi ve kariyer gelişimi için mevcut fırsatları göz önüne aldıkları; olumsuz bakan öğrencilerin ise ağır çalışma koşulları ve iş ortamı nedeniyle olumsuz algılara sahip olduğu kaydedilmiştir (Wijesundara, 2015). Söz konusu algılar açısından turizm eğitiminin etkinliği de göz önüne alınabilir. Örneğin, turizm eğitiminin önemli bir aşaması olan lisans, önlisans ve yüksekokul eğitimine yönelik 2017 yılı kontenjan ve başvuru durumlarının incelendiği bir çalışmada, önlisans ve yüksekokul programlarındaki kontenjanların yaklaşık \% 25 oranında boş kaldığı tespit edilmiştir (Yayla vd. 2017). Turizm eğitimi alan öğrencilerin sektöre yönelik tutumlarını belirlemeyi amaçlayan araştırmalarda; turizm sektörünün işgücü ihtiyacını, turizm eğitimi almamış kişileri istihdam ederek karşıladığı; turizm eğitimi alanların genellikle sektörü terk ettikleri ve başka sektörlerde çalışmak istedikleri tespit edilmiştir (Üngüren ve Ehtiyar, 2009). Söz konusu araştırmalarda, öğrencilerin bölümleri ve mezuniyet sonrasında sektördeki iş imkanları ile ilgili bakış açılarında zamanla olumsuz yönde değişimler saptanmış, öğrencilerin çoğunluğunun seçtiği bölümden pişman oldukları ve sektöre karşı olumsuz tutum ve görüşlerinin olduğu ifade edilmiştir. Turizm eğitimi almış mezunların sektördeki çalışma koşullarının zor olması, gelişim fırsatlarının sınırlı kalması, motivasyon yetersizliği 
ve iş tatminsizliği gibi sebeplerle sektörü terk ettikleri saptanmıştır (Üngüren ve Ehtiyar, 2009). Ayrıca iş deneyimine sahip olan öğrencilerin, deneyim sahibi olmayan öğrencilere oranla terfi ile ilgili daha olumsuz bir bakış açısına sahip oldukları da görülmektedir (Bahçelerli ve Sucuoğlu, 2015).

Turizm eğitimi almakta olan öğrencilerin, turizmin doğasını ve çalışma koşullarını ağır, ücret ve ek gelirleri ise düşük buldukları tespit edilmiştir (Duman vd., 2006). Bu olumsuz görüşün sebepleri olarak, yükseköğretim kurumlarında sunulan turizm eğitiminin öğrencilerin beklentilerini karşılamadığı, turizm işletmeciliği öğrencilerinin beklentilerinin sektörle uyuşmadığı, çalışma koşullarının öğrencileri olumsuz tutum içerisine sürüklediği ve bu yüzden öğrencilerin tatmin düzeylerinin oldukça düşük olduğu ifade edilmiştir (Üngüren ve Ehtiyar, 2009). Bunların yanında, yapılan diğer araştırmalarda ise, turizm eğitimi alan öğrencilerin çok büyük bir kısmının ilerde kendi işini kurmak istedikleri tespit edilmiştir (Solmaz vd., 2014). Öğrencilerin eğitimlerini, kendi işyerlerini kurmak için kullanma eğiliminde oldukları ve kendi işyerlerine sahip olmayı kariyerlerinin bir parçası olarak gördükleri söylenebilir (Çarıkçı ve Morçin, 2014). Öğrencilerin turizm sektöründe çalışma ile ilgili beklentileri açısından bakıldığında gençlerin statü olarak yönetici pozisyonunda çalışmayı istedikleri ve çalışacakları işyerini seçerken önce kariyer ve maaş olanaklarına dikkat ettikleri tespit edilmiştir (Cömert 2014, Üzümcü vd. 2015). Ayrıca sorunsuz bir ortamda çalışmayı ve yaptıkları işten tatmin olmayı istemektedirler (Sarışık, 2007). Araştırmalar, öğrencilerin staj yapmalarının ve öğrencilikleri devam ederken iş deneyimi elde etmelerinin, turizm sektöründeki kariyer planları ile ilgili olumsuz algılarını azalttığını da göstermektedir (Kim ve Park, 2013)

Meslek seçimi insan hayatında oldukça önemli bir karardır. Meslek seçimi öncesinde, seçilecek meslekle ilgili iş gerekleri, çalışma şartları, avantajlar, dezavantajlar ve kişilik özellikleri ile ilgili araştırmalar yapılmalıdır. Turizm sektöründe istihdam edilecek bireylerin dışadönük, yumuşak başl1, sorumlu ve duygusal olarak dengeli olmalarına özen gösterilmesi gerekmektedir (Aslan vd., 2012). Genel olarak araştırmalar, öğrencilerin turizm bölümünü bilinçsiz bir şekilde tercih ettiklerini, sadece bir üniversite okuma düşüncesiyle geldiklerini, günün şartlarında geçerli bir meslek 
olarak gördüklerinden dolayı seçtiklerini, üst sınıflardaki öğrencilerin gelecek kaygısının arttığını ve eğitimden duydukları memnuniyetin azaldığını göstermektedir (Baltacı vd., 2012). Yapılan çalışmalar, öğrencilerin meslek seçimlerinde genel olarak ilginç ve rekabetçi çalışma ortamı, kariyer ve gelişim fırsatları ve iyi çalışma koşullarına değer verdiklerini ancak turizm endüstrisinde kendileri açısından önemli gördükleri tüm bu motive edici faktörlerin eksik olduğuna inandıklarını göstermektedir (Grobelna, 2017).

Meslek seçimi açısından bakıldığında, turizm meslek lisesinden mezun olan öğrencilerin bu mesleği daha çok sevdikleri ve benimsedikleri, genel lise mezunlarının ise tam tersi davranış gösterdikleri görülmektedir (Olcay ve Çelik, 2010). Okuduğu bölümü isteyerek seçenlerin istemeyerek seçenlere kıyasla turizm sektöründe çalışma eğilimlerine yönelik tutumları, anlamlı bir şekilde yüksek bulunmuştur (Köşker ve Unur, 2017). Mesleki turizm deneyimi elde etmiş öğrencilerin büyük bölümünün mesleğin geleceğine ilişkin olumlu tutum içinde oldukları, turizm sektöründe çalışmayı eğlenceli ve zevkli buldukları ifade edilebilir. Ayrıca meslek lisesinden gelen öğrencilerin sektöre yönelik bir farkındalığa sahip oldukları ve iyi bir ücret ile hızlı yükselme imkânlarına yönelik algıların da bu farkındalıkla oluştuğu düşünülmektedir (Üzümcü vd., 2015). Seyahat acentac1lığı, konaklama işletmeciliği ve turist rehberliği bölümlerinde okuyan öğrencilerin eğitim memnuniyetleri ise turizm işletmeciliği bölümü öğrencilerine oranla daha yüksek bulunmuştur (Baltacı vd. 2012). Öğrenciler sektörde çalışmanın kolay olduğuna katılmamakla birlikte, işlerinde çabuk yükselebileceklerine inanmaktadırlar (Sarışık, 2007). Öğrencilerin mezuniyet sonrası farklı sektörlere yönelmesinin önlenmesi için sektörde istihdam edilmelerinin sağlanması, çalışma şartlarının iyileştirilmesi ve Turizm Personeli Meslek Yasası'nın çıkartılmasının gerektiği ifade edilmektedir (Orhan, 2015).

Demografik özellikler açısından bakıldığında ise, cinsiyet, yaş, mezun oldukları lise türü, öğrenim görülen sınıf, staj durumu ve eğitim alınan bölüm turizm öğrencilerinin bu değişkenlere göre, meslek algılarının ve meslekten beklentilerinin farklı olduğu görülmektedir (Sarışık, 2007, Olcay ve Çelik 2010, Avc1, 2011). Öğrencilerin turizm sektöründeki departmanlara yönelik olarak da orta düzeyde olumlu bir tutuma sahip oldukları ve öğrencilerin tutumlarının bir takım demografik özelliklerine göre 
farklılık gösterdiği belirlenmiştir (Tekin ve Deniz, 2015). Cinsiyet açısından, turizm sektöründe bazı işlerin kadın işi bazı işlerin erkek işi olarak düşünüldüğü algısı görülmektedir. (Cömert 2014). Kız öğrencilerin insanlarla sürekli iletişim kurabilecekleri bir alan olduğu için sektörü tercih ettikleri, erkek öğrencilerin ise gelecekte bu sektörde kendi işini kurabilme beklentisi içinde oldukları (Sarışık, 2007), kadınların erkeklere oranla turizm sektöründe çalışma eğilimlerine yönelik tutumlarının daha olumlu olduğu (Köşker ve Unur, 2017) tespit edilmiştir. Ayrıca öğrencilerin, erkeklerin en fazla çalışmak isteyecekleri bölümün servis, kadınların en fazla çalışmak isteyecekleri bölümün ise kat hizmetleri olacağını düşündükleri (Cömert 2014), erkek öğrencilerin eğitimden duydukları memnuniyetin, kız öğrencilere göre daha düşük düzeyde olduğu ve erkek öğrencilerin gelecek kaygısının kız öğrencilere göre daha yüksek olduğu ortaya konulmuştur (Baltacı vd. 2012).

Araştırmalarda, öğrencilerin genel olarak turizm eğitimini gönüllü olarak seçtikleri ve kız öğrencilerin erkek öğrencilere oranla sektörle ilgili daha olumlu düşünceleri olduğu görülmekte, buradan hareketle, kız öğrencilerin turizm mesleğini daha ilginç, çalışmaya değer ve keyifli buldukları ifade edilmektedir (Bahçelerli ve Sucuoğlu, 2015).

Turizm sektöründeki iş ve kariyer olanaklarının değerlendirilmesi açsından, lisans ve lise öğrencileri, önlisans öğrencilerine göre daha olumlu tavır göstermektedir. Öğrencilerin eğitim seviyeleri ve cinsiyetlerine göre sektörün çalışma koşullarını algılamaları ve sektörde çalışma isteklerine ilişkin düşüncelerinde farklılıklar bulunmuş ve öğrencilerin sektörde çalışma isteklerini etkileyen en önemli unsurlar kişi-endüstri uyumu, terfi imkânları ve sektörde çalışmanın sağlayacağı sosyal statü olarak ortaya konulmuştur. (Duman vd., 2006).

Turizm sektörünün öğrenciler tarafından algılanan olumsuz özellikleri, öğrencilerin mezun olduktan sonra bu sektörde kariyer arayışına olan ilgisini azaltmaktadır. Oysa mezunların turizm sektöründe istihdamı, özellikle sektörün geleceği ve yüzleştiği nitelikli çalışan eksikliği sorunu bakımından oldukça önemlidir (Zubaidah vd., 2016). Sektörün, imajını iyileştirmesi ve öğrencilerin mezun olduktan sonra turizm endüstrisine girmelerini teşvik etmek için özel beklentilerini karşılayan kariyer fırsatlarının geliştirmesi gerekmektedir (Grobelna, 2017) 


\section{Yöntem}

Bu çalışma ile Otel Lokanta ve İkram Hizmetleri ile Seyahat Turizm ve Eğlence Hizmetleri ön lisans düzeyinde öğrenim gören öğrencilerin turizm mesleğine yönelik algı farklılıklarını ortaya çıkarmak amaçlanmaktadır. Bu amaç doğrultusunda Pamukkale Üniversitesi Sosyal Bilimler Meslek Yüksekokulu'nda ön lisans öğrenimi gören öğrencilere turizm mesleği ile ilgili bir anket uygulaması yapılmıştır.

Veri toplama aracı olarak kullanılan anket formu, Karaman (2008) tarafından öğretmenlerin mesleki algılarını ölçmek için geliştirilen, Yılmaz, Şen ve Demirkaya (2014) tarafından, hemşirelerin ve ebelerin mesleki algılarını ölçmek için uyarladıkları ve Yılmaz ve Tanrıverdi tarafından aşçılar için uyarlanan (2017) anket sorularından seçilerek turizm öğrencileri için uyarlanmıştır. Ölçek 46 ifadeden oluşturulmuş ve her ifade 5'li Likert ölçeği kullanılarak değerlendirilmiştir.

Araştırma 2017-2018 öğretim yılı bahar döneminde Denizli Sosyal Bilimler Meslek Yüksekokulunda Otel Lokanta ve İkram Hizmetleri ile Seyahat Turizm ve Eğlence Hizmetleri bölümleri normal ve ikinci öğretim öğrencilerinden derse devam eden 1 . ve 2 . Sınıf öğrencilerine uygulanmıştır. Elde edilen 420 anketten geçerli olan 382 tanesi değerlendirmeye alınmiştır.

Turizm mesleğine yönelik algıyı ölçmekte kullanılan ölçeklerin geçerlilik ve güvenilirlik çalışması yapılmış, geçerlilik çalışması için Karaman (2008), Yılmaz, Şen ve Demirkaya (2014) ve Yılmaz ve Tanrıverdi (2017) kullandıkları ölçeklerden uyarlanan ifadelerin yüzey geçerliliğine bakılmış ve literatür ile kavramsal uygunluk ölçek maddelerinin geçerliliği için yeterli kabul edilmiştir. Ölçekler için Cronbach Alpha katsayısı hesaplanmıştır. Ölçeğin Cronbach Alpha katsayısı 0,916 olarak bulunmuştur. Bu doğrultuda bu sonuç Hair vd. (1995, s.118) tarafından önerilen 0,70 değerini aştığ 1 için ölçekler güvenilir kabul edilmiştir.

\section{Bulgular}

Çalışmanın bulgular kısmında öncelikle öğrencilerin demografik özellikleri eğitim durumu, sınıfları, normal veya ikinci öğretim öğrencisi olma 
durumları incelenmektedir. Ayrıca araştırmaya katılan öğrencilere Turizm Bölümü'nü isteyerek seçip seçmediği soruları sorulmuştur. Bu sorulara verilen yanitlar Tablo 1'de verilmiştir.

Tablo 1: Örneklemin Demografik Özellikleri ve Öğrenim Durumları

\begin{tabular}{llllll}
\hline Cinsiyet & Frekans & $\mathbf{( \% )}$ & Öğretim & Frekans & $\mathbf{( \% )}$ \\
\hline Kadın & 165 & 43,2 & Normal Öğretim & 195 & 51,0 \\
\hline Erkek & 217 & 56,8 & İkinci Öğretim & 187 & 49,0 \\
\hline Toplam & $\mathbf{3 8 2}$ & $\mathbf{1 0 0 , 0}$ & Toplam & $\mathbf{3 8 2}$ & $\mathbf{1 0 0 , 0}$ \\
\hline Öğrenim Durumu & Frekans & $\mathbf{( \% )}$ & Sınıf & Frekans & $\mathbf{( \% )}$ \\
\hline Normal Lise & 114 & 29,8 & 1 & 177 & 46,3 \\
\hline Turizm Lisesi & 109 & 28,5 & 2 & 205 & 53,7 \\
\hline Meslek Lisesi & 159 & 41,6 & Toplam & 382 & 100,0 \\
\hline Toplam & $\mathbf{3 8 2}$ & $\mathbf{1 0 0 , 0}$ & İsteyerek/İstemeyerek & Frekans & $\mathbf{( \% )}$ \\
\hline Yaş & Frekans & $\mathbf{( \% )}$ & Evet & 262 & 68,6 \\
\hline 17-19 & 58 & 15,2 & Hayır & 119 & 31,2 \\
\hline $20-22$ & 270 & 70,7 & Toplam & $\mathbf{3 8 1}$ & $\mathbf{9 9 , 8}$ \\
\hline $23-25$ & 41 & 10,7 & Bölüm & Frekans & $\mathbf{( \% )}$ \\
\hline $26-28$ & 8 & 2,1 & Turizm Otel & 204 & 53,4 \\
\hline 29 ve üstü & 5 & 1,3 & Turizm Seyahat & 178 & 46,6 \\
\hline Toplam & $\mathbf{3 8 2}$ & $\mathbf{1 0 0 , 0}$ & Toplam & $\mathbf{3 8 2}$ & $\mathbf{1 0 0}$ \\
\hline & & & & &
\end{tabular}

Pamukkale Üniversitesi Denizli Sosyal Bilimler Meslek Yüksekokulu'nda öğrenim gören öğrencilerin demografik verilerine bakıldığında, katılımcların çoğunluğunu erkekler oluşturmaktadır. Katılımcılar içindeki erkek öğrencilerin oranı $\% 56,8$ kadın öğrencilerin oranı da $\% 43,2$ 'dir. Katılımcıların normal ve ikinci öğretim olarak katılımları \%51'e \%49 şeklinde eşit denebilecek düzeydedir. Öğrenim durumlarında öğrencilerin hangi tür bir liseden mezun oldukları sorulmuştur. Katılımcıların \%29,8'i normal lise, 28,5'i turizm lisesi ve 41,6'sı meslek lisesi çıkışlıdır. Örneklemin kaçıncı sınıfta olduklarına bakıldığında ise \%46,3 birinci sınıf, $\% 53,7$ 'inin ikinci sınıf olduğu görülmektedir.

Yaşlarına göre dağılımları incelendiğinde \%70,7'sinin 20-22 yaş aralığında olduğu, \%15,2'sinin 17-19, \%10,7'sinin 23-25, \%2,1'nin 26-28 ve 1,3'ünün 29 ve üstü olduğu anlaşılmıştır. Önemli sorulardan biri okudukları bölüme isteyerek mi geldikleri sorusudur. Bu soruya evet diyenler $\% 68,6$ ve hayır diyenler \%31,2'lik bir orana sahiptir bir kişi bu soruyu yanıtsız bırakmıştır. Denizli Sosyal Bilimler Meslek Yüksekokulu'nda iki tu- 
rizm bölümü bulunmaktadır. Katılımcıların \%53,4'ü Otel Lokanta ve İkram Hizmetleri bölümünde, \%46,6'sı ise Seyahat Turizm ve Eğlence Hizmetleri bölümünde öğrenci olarak devam etmektedir.

\section{Turizm Öğrencilerinin Turizm Mesleğine Yönelik Algı Farklılıkları}

Katılımcıların ölçek ifadelerine ilişkin katılım durumlarını belirten ortalamalar ve standart sapmaları tablo 2'de verilmiştir. Değerlendirmeye alınan 382 adet anket formunda öğrencilerin en yüksek katılım düzeyi 4,1597 ortalama ile "Turizmde farklı milletlerden insanlarla tanışmak mutlu edici bir tecrübedir" ifadesinedir. Öğrencilerin farklı kültürlerden ve milletlerden insanlarla tanışmalarının onları mutlu ettiği ve turizm mesleğine olumlu algıya katkı sağladığı görülmektedir.

Öğrencilerin en düşük düzeyde katılım gösterdiği $(2,7670)$ “Kendini geliştirme imkânları azdır" ifadesi de turizmde çalışanların kendilerini geliştirme imkânlarının fazla olarak görüldüğü ve turizm algısını olumlu yönde etkilediği görülmektedir. Ancak öğrencilerin çalışma alanı olarak turizmi seçmelerine ilişkin "Turizmden başka bir alanda çalışmayı düşünemem" ve "Başka bir meslek seçme imkânım olsa, yine turizmi seçerdim" ifadelerine katılım oranlarının düşük olması öğrencilerin turizm alanında çalışmaya sıcak bakmadıkları ve başka sektörlerde ortaya çıkabilecek fırsatlarda sektör değiştirmeyi düşünecekleri anlamı çıkarılabilir.

Tablo 2: Turizm Mesleğine Yönelik Algı Farklılıkları (n=382)

\begin{tabular}{llll}
\hline & $\mathbf{N}$ & ort & ss \\
\hline 1.Turizm endüstrisinde çalışmak ilgi çekicidir & 382 & 3,7225 & 1,00470 \\
\hline 2.Turizm endüstrisinde çalışacak olmaktan mutluyum & 382 & 3,4346 & 1,07448 \\
\hline 3.Turizm itibarlı bir meslektir & 382 & 3,5602 & 1,08692 \\
\hline 4.Daha fazla eğitim fırsatları sunan bir meslektir & 382 & 3,5471 & 1,06809 \\
\hline 5.Çalışma arkadaşlarıyla iyi anlaşama ortamı sağlamaktadır & 382 & 3,7382 & 1,01669 \\
\hline 6.Her yerde iş bulma imkânı sunmaktadır & 382 & 3,4215 & 1,13538 \\
\hline 7.Yurt dışına çıma fırsatı sunmaktadır & 382 & 3,8141 & 1,07684 \\
\hline 8.Turizm endüstrisinde terfi olanakları memnun edicidir & 382 & 3,6990 & 0,90837 \\
\hline 9.Turizm, eğlenceli bir meslektir. & 382 & 3,8508 & 1,07280 \\
\hline 10.Topluma fayda sağlayabileceğim bir meslektir & 382 & 3,6492 & 1,03862 \\
\hline 11.Bu meslek, yeteneklerimi ve kabiliyetlerimi kullanabilme imkânı sağ- & 382 & 3,8089 & 1,01827 \\
lar & 382 & 3,4607 & 1,03851 \\
\hline 12.Bu meslek bağımsız olmamı sağlar & 382 & 3,4974 & 0,97676 \\
\hline 13.Yüksek nitelikli iş yapma donanımı mevcuttur & 382 & 3,8901 & 0,96035 \\
\hline 14.Sorumluluk veren bir meslektir. & &
\end{tabular}


Turizm Eğitimi Alan Önlisans Öğrencilerinin Sektöre Yönelik Meslek Algıları:

Pamukkale Üniversitesi Örneği

\begin{tabular}{|c|c|c|c|}
\hline 15.Turizm endüstrisinde kurumsallaşmamış bir yapı vardır & 382 & 3,4031 & 1,03978 \\
\hline $\begin{array}{l}\text { 16.Turizm endüstrisinde kariyer yapmak diğer sektörlere kıyasla daha } \\
\text { kolaydır }\end{array}$ & 382 & 3,2513 & 1,15228 \\
\hline 17.Turizmde çalışmayla iyi para kazanılır. & 382 & 3,7094 & 1,06575 \\
\hline $\begin{array}{l}\text { 18.Turizmde farklı milletlerden insanlarla tanışmak mutlu edici bir tec- } \\
\text { rübedir. }\end{array}$ & 382 & 4,1597 & 0,91250 \\
\hline 19.Turizmde cinsiyet ayrımcılığı yoktur & 382 & 3,9267 & 1,13862 \\
\hline $\begin{array}{l}\text { 20.Çalışanlara sunulan yemekhane, yatakhane, banyo imkânları iyi du- } \\
\text { rumdadır }\end{array}$ & 382 & 3,1728 & 1,11374 \\
\hline $\begin{array}{l}\text { 21.Turizm işletmeleri içerisinde daha çok otokratik yöneticiler çalışmak- } \\
\text { tadır }\end{array}$ & 382 & 3,3639 & 0,95903 \\
\hline 22.Turizm işletmelerinde hakkaniyetli terfi anlayışı düşüktür & 382 & 3,3586 & 1,06220 \\
\hline 23.Kendini geliştirme imkânları azdır & 382 & 2,7670 & 1,22770 \\
\hline 24.Eğitimsiz insanlar önemli pozisyonlarda görev alabilmektedir & 382 & 3,6440 & 3,64400 \\
\hline 25.Turizm işletmelerinin toplum nezdinde kötü imajı vardır & 382 & 2,7958 & 1,13646 \\
\hline 26.Turizm endüstrisi kırılgan bir yapı göstermektedir & 382 & 3,5079 & 0,88362 \\
\hline 27.Turizmde işgören hakları yeterli seviyede gelişememiştir & 382 & 3,4188 & 1,13288 \\
\hline 28.Turizm endüstrisinde sosyal güvence eksiktir & 382 & 3,1571 & 1,15080 \\
\hline 29.Turizm endüstrisinde teori ve pratik farklılık göstermektedir & 382 & 3,5785 & 0,98964 \\
\hline 30.Turizm ile ilgili yasal zeminde boşluklar mevcuttur & 382 & 3,4424 & 1,01979 \\
\hline 31.Turizm işletmelerinde işten keyfi çıkarmalar olabilmektedir & 382 & 3,5209 & 1,14481 \\
\hline 32.Çalışma koşulları aile yaşamını olumsuz etkilemektedir & 382 & 3,4293 & 1,21840 \\
\hline 33.Turizm işletmelerinde iş yükü oldukça fazladır & 382 & 3,7225 & 1,10426 \\
\hline 34.Turizmde çalışmak gelecek garantisini sağlamaz & 382 & 3,3639 & 1,22573 \\
\hline 35.Turizmde düzensiz ve uzun çalışma saatleri vardır & 382 & 3,7670 & 1,15727 \\
\hline 36.Turizmde iş güvenliği riski çok yüksektir & 382 & 3,2094 & 1,13087 \\
\hline $\begin{array}{l}\text { 37.Turizm çalışanları eğitilmiş iş gücüne yönelik önyargılı davranmakta- } \\
\text { dır }\end{array}$ & 382 & 3,2251 & 1,06315 \\
\hline 38.Çalışanların eğitim seviyesi genelde düşüktür & 382 & 3,3508 & 1,17609 \\
\hline 39.İnsanlar tatildeyken onlara hizmet etmek güzel değildir & 382 & 3,0366 & 1,19874 \\
\hline $\begin{array}{l}\text { 40.Turizmin mevsimsel olması kariyerim açısından sakınca yaratmakta- } \\
\text { dır }\end{array}$ & 382 & 3,4555 & 1,12563 \\
\hline $\begin{array}{l}\text { 41.Turizm işletmeciliği eğitimi almam kariyer gelişimimde doğru bir ka- } \\
\text { rardır }\end{array}$ & 382 & 3,4921 & 1,05427 \\
\hline 42.Entelektüel bir fırsat yaratan kariyer imkânı sağlamaktadır & 382 & 3,4529 & 1,02802 \\
\hline 43.Turizm endüstrisinde kariyer yapma imkânları azdır & 382 & 3,1545 & 1,17931 \\
\hline 44.Turizmi bir kariyer yolu olarak seçmemden dolayı çok mutluyum & 382 & 3,2723 & 1,10081 \\
\hline 45.Turizmden başka bir alanda çalışmayı düşünemem & 382 & 2,9058 & 1,26596 \\
\hline 46.Başka bir meslek seçme imkânım olsa, yine turizmi seçerdim. & 382 & 2,9188 & 1,32261 \\
\hline
\end{tabular}

Turizm öğrencilerinin turizm mesleğine yönelik algılamalarındaki farkl1lıkları belirlemek amacıyla bağımsız t-testi ve Anova testleri uygulanmıştır. Öğrencilerini cinsiyetlerine göre fark olup olmadığını anlamak için yapılan t-testi sonucunda ifadelerden sadece birinde anlamlı bir fark olduğu ortaya çıkmıştır. Tablo 3'de belirtilen sonuçlara göre “Turizm endüstrisi 
kırılgan bir yapı göstermektedir" ifadesine erkek öğrencilerin katılım oranı kadın öğrencilere göre daha yüksek çıkmıştır.

Tablo 3: Cinsiyete göre mesleki algı durumu

\begin{tabular}{|c|c|c|c|c|c|c|}
\hline İfade & Cinsiyet & $\mathrm{N}$ & Ort. & Std.Sapma & & $\begin{array}{l}\text { Sig } \\
(2 \text { tailed })\end{array}$ \\
\hline \multirow{2}{*}{$\begin{array}{l}\text { Turizm endüstrisi kırılgan bir } \\
\text { yapı göstermektedir }\end{array}$} & Kadın & 165 & 3,387 & 0,84527 & \multirow{2}{*}{$-2,327$} & \multirow{2}{*}{0,020} \\
\hline & Erkek & 217 & 3,599 & 0,90298 & & \\
\hline
\end{tabular}

Turizm öğrencilerinin öğretim durumlarına göre, örgün öğretim ve ikinci öğretim öğrencilerinin mesleki algılamalarında "Turizmde işgören hakları yeterli seviyede gelişememiştir" ifadesinde anlamlı bir farklılık olduğu Tablo 4'de görülmektedir. Örgün öğretim okuyan öğrencilerin işgören haklarının yeterince gelişmediği fikrine ikinci öğretim öğrencilere göre daha fazla katılmaktadırlar. Ancak her iki grup ortalamalarının üçün üzerinde olması öğrencilerin ağırlıklı olarak bu fikre katıldığını göstermektedir.

Tablo 4: Örgün öğretim ve ikinci öğretim öğrencilerinin mesleki algı durumu

\begin{tabular}{lllllll}
\hline & Öğretim & $\mathrm{N}$ & Ort. & Std.Sapma & $\mathrm{t}$ & $\begin{array}{l}\text { Sig } \\
\text { (2 tailed) }\end{array}$ \\
\cline { 1 - 6 } $\begin{array}{l}\text { Turizmde işgören hakları ye- } \\
\text { terli seviyede gelişememiştir }\end{array}$ & Normal & 195 & 3,579 & 1,13863 & 2,857 & 0,005 \\
\cline { 2 - 6 } & İkinci & 187 & 3,251 & 1,10519 & \\
\hline
\end{tabular}

Turizm öğrencilerinin bulundukları sınıfa göre mesleki algılamalarında ortaya çıkan farklılıklar Tablo 5' de verilmiştir. Bu tabloya göre “Turizmde farklı milletlerden insanlarla tanışmak mutlu edici bir tecrübedir" ifadesine her iki sınıf öğrencilerinin katılım oranları yüksek olmakla beraber birinci sınıf öğrencilerinin katılım oranları diğerine göre daha yüksek olmuştur. "Turizm çalışanları eğitilmiş iş gücüne yönelik önyargılı davranmaktadır", "Çalışanların eğitim seviyesi genelde düşüktür" ve İnsanlar tatildeyken onlara hizmet etmek güzel değildir" ifadelerine katılım durumları ikinci sinıfların birinci sinıflara göre ve genel ortalamaya göre daha yüksektir. Bunun sebebi olarak ikinci sınıfların stajlarını genellikle birinci sınıf bittikten sonra yapmaları ve sektöre ilişki deneyim edinmiş olmaları olarak gösterilebilir. 
Tablo 5: Okudukları sınıfa göre öğrencilerin mesleki algı durumu

\begin{tabular}{|c|c|c|c|c|c|c|}
\hline İfade & Sinif & $\mathrm{N}$ & Ort. & Std.Sapma & $\mathrm{t}$ & $\begin{array}{l}\text { Sig } \\
(2 \text { tailed })\end{array}$ \\
\hline \multirow{2}{*}{$\begin{array}{l}\text { Turizmde farklı milletlerden } \\
\text { insanlarla tanışmak mutlu } \\
\text { edici bir tecrübedir. }\end{array}$} & 1 & 177 & 4,271 & 0,82910 & \multirow[b]{2}{*}{2,231} & \multirow[b]{2}{*}{0,026} \\
\hline & 2 & 205 & 4,063 & 0,97059 & & \\
\hline \multirow{2}{*}{$\begin{array}{l}\text { Turizm çalışanları eğitilmiş iş } \\
\text { gücüne yönelik önyargılı } \\
\text { davranmaktadır }\end{array}$} & 1 & 177 & 3,107 & 1,03067 & \multirow[b]{2}{*}{$-2,020$} & \multirow[b]{2}{*}{0,044} \\
\hline & 2 & 205 & 3,326 & 1,08262 & & \\
\hline \multirow{2}{*}{$\begin{array}{l}\text { Çalışanların eğitim seviyesi } \\
\text { genelde düşüktür }\end{array}$} & 1 & 177 & 3,203 & 1,20293 & \multirow{2}{*}{$-2,289$} & \multirow{2}{*}{0,023} \\
\hline & 2 & 205 & 3,478 & 1,14007 & & \\
\hline \multirow{2}{*}{$\begin{array}{l}\text { İnsanlar tatildeyken onlara } \\
\text { hizmet etmek güzel değildir }\end{array}$} & 1 & 177 & 2,898 & 1,25266 & \multirow{2}{*}{$-2,105$} & \multirow{2}{*}{0,036} \\
\hline & 2 & 205 & 3,156 & 1,13976 & & \\
\hline
\end{tabular}

Bu çalışmadaki önemli bölümlerden biri de turizm bölümlerinde eğitim almakta olan öğrencilerin bu bölümlere "kendi istekleriyle mi?" geldikleri sorusu ve kendi isteğiyle gelenler ile çeşitli sebeplerle istemeden gelenler arasındaki algı farklılıklarıdır. Bunu belirlemek amacıyla yapılan t-testi sonuçları Tablo 6'da verilmiştir.

Tablo 6 incelendiğinde turizm bölümlerine isteyerek gelen öğrencilerin turizme yönelik olumlu ifadelerde istemeyerek gelenlere göre belirgin bir şekilde farklılaştıkları ve daha yüksek ortalamalara sahip oldukları görülmektedir.

Tablo 6: Okudukları bölümü isteyerek tercih eden ve istemeden gelen öğrencilerin mesleki algi durumu

\begin{tabular}{|c|c|c|c|c|c|c|}
\hline İfade & $\begin{array}{l}\text { İstek } \\
\text { durumu }\end{array}$ & $\mathrm{N}$ & Ort. & $\begin{array}{l}\text { Std. } \\
\text { Sap } \\
\text { ma }\end{array}$ & $\mathrm{t}$ & $\begin{array}{l}\text { Sig } \\
\text { (2 tai- } \\
\text { led) }\end{array}$ \\
\hline \multirow{2}{*}{$\begin{array}{l}\text { Turizm endüstrisinde çalışmak ilgi çekici- } \\
\text { dir }\end{array}$} & İsteyerek & 262 & 3,935 & 0,95 & \multirow{2}{*}{6,463} & \multirow{2}{*}{0,000} \\
\hline & İstemeden & 119 & 3,252 & 0,94 & & \\
\hline \multirow{2}{*}{$\begin{array}{l}\text { Turizm endüstrisinde çalışacak olmaktan } \\
\text { mutluyum }\end{array}$} & İsteyerek & 262 & 3,667 & 1,06 & \multirow{2}{*}{7,090} & \multirow{2}{*}{0,000} \\
\hline & İstemeden & 119 & 2,916 & 0,90 & & \\
\hline \multirow[t]{2}{*}{ Turizm itibarlı bir meslektir } & İsteyerek & 262 & 3,725 & 1,05 & \multirow{2}{*}{4,460} & \multirow{2}{*}{0,000} \\
\hline & İstemeden & 119 & 3,201 & 1,07 & & \\
\hline \multirow{2}{*}{$\begin{array}{l}\text { Daha fazla eğitim firsatları sunan bir mes- } \\
\text { lektir }\end{array}$} & İsteyerek & 262 & 3,717 & 1,01 & \multirow{2}{*}{4,584} & \multirow{2}{*}{0,000} \\
\hline & İstemeden & 119 & 3,193 & 1,09 & & \\
\hline \multirow{2}{*}{$\begin{array}{l}\text { Çalışma arkadaşlarıyla iyi anlaşama or- } \\
\text { tamı sağlamaktadır }\end{array}$} & İsteyerek & 262 & 3,896 & 0,90 & \multirow{2}{*}{4,253} & \multirow{2}{*}{0,000} \\
\hline & İstemeden & 119 & 3,386 & 1,15 & & \\
\hline \multirow[t]{2}{*}{ Her yerde iş bulma imkânı sunmaktadır } & İsteyerek & 262 & 3,522 & 1,09 & \multirow{2}{*}{2,512} & \multirow{2}{*}{0,012} \\
\hline & İstemeden & 119 & 3,210 & 1,19 & & \\
\hline \multirow[t]{2}{*}{ Yurt dışına çıkma fırsatı sunmaktadır } & İsteyerek & 262 & 3,946 & 1,00 & \multirow{2}{*}{3,501} & \multirow{2}{*}{0,001} \\
\hline & İstemeden & 119 & 3,512 & 1,17 & & \\
\hline \multirow{2}{*}{$\begin{array}{l}\text { Turizm endüstrisinde terfi olanakları } \\
\text { memnun edicidir }\end{array}$} & İsteyerek & 262 & 3,774 & 0,85 & \multirow{2}{*}{2,321} & \multirow{2}{*}{0,021} \\
\hline & İstemeden & 119 & 3,529 & 0,99 & & \\
\hline Turizm, eğlenceli bir meslektir. & İsteyerek & 262 & 3,961 & 1,02 & 2,983 & 0,003 \\
\hline
\end{tabular}




\begin{tabular}{|c|c|c|c|c|c|c|}
\hline & İstemeden & 119 & 3,596 & 1,14 & & \\
\hline \multirow{2}{*}{$\begin{array}{l}\text { Bu meslek, yeteneklerimi ve kabiliyetle- } \\
\text { rimi kullanabilme imkânı sağlar }\end{array}$} & İsteyerek & 262 & 3,904 & 0,97 & \multirow{2}{*}{2,723} & \multirow{2}{*}{0,007} \\
\hline & İstemeden & 119 & 3,588 & 1,08 & & \\
\hline \multirow[t]{2}{*}{ Bu meslek bağımsız olmamı sağlar } & İsteyerek & 262 & 3,545 & 0,99 & \multirow{2}{*}{2,425} & \multirow{2}{*}{0,016} \\
\hline & İstemeden & 119 & 3,268 & 1,11 & & \\
\hline \multirow{2}{*}{$\begin{array}{l}\text { Yüksek nitelikli iş yapma donanımı mev- } \\
\text { cuttur }\end{array}$} & İsteyerek & 262 & 3,599 & 0,96 & \multirow{2}{*}{3,091} & \multirow{2}{*}{0,002} \\
\hline & İstemeden & 119 & 3,268 & 0,96 & & \\
\hline \multirow[t]{2}{*}{ Sorumluluk veren bir meslektir. } & İsteyerek & 262 & 3,973 & 0,90 & \multirow{2}{*}{2,472} & \multirow{2}{*}{0,014} \\
\hline & İstemeden & 119 & 3,697 & 1,05 & & \\
\hline \multirow{2}{*}{$\begin{array}{l}\text { Turizmde farklı milletlerden insanlarla ta- } \\
\text { nışmak mutlu edici bir tecrübedir. }\end{array}$} & İsteyerek & 262 & 4,251 & 0,86 & \multirow{2}{*}{3,029} & \multirow{2}{*}{0,003} \\
\hline & İstemeden & 119 & 3,949 & 0,99 & & \\
\hline \multirow{2}{*}{$\begin{array}{l}\text { Turizmde düzensiz ve uzun çalışma saat- } \\
\text { leri vardır }\end{array}$} & İsteyerek & 262 & 3,877 & 1,08 & \multirow{2}{*}{2,648} & \multirow{2}{*}{0,009} \\
\hline & İstemeden & 119 & 3,521 & 1,27 & & \\
\hline \multirow{2}{*}{$\begin{array}{l}\text { Turizm çalışanları eğitilmiş iş gücüne yö- } \\
\text { nelik önyargılı davranmaktadır }\end{array}$} & İsteyerek & 262 & 3,293 & 1,02 & \multirow{2}{*}{2,013} & \multirow{2}{*}{0,045} \\
\hline & İstemeden & 119 & 3,058 & 1,12 & & \\
\hline \multirow{2}{*}{$\begin{array}{l}\text { Turizm işletmeciliği eğitimi almam kari- } \\
\text { yer gelişimimde doğru bir karardır }\end{array}$} & İsteyerek & 262 & 3,603 & 1,03 & \multirow{2}{*}{3,115} & \multirow{2}{*}{0,002} \\
\hline & İstemeden & 119 & 3,243 & 1,06 & & \\
\hline \multirow{2}{*}{$\begin{array}{l}\text { Entelektüel bir fırsat yaratan kariyer } \\
\text { imkânı sağlamaktadır }\end{array}$} & İsteyerek & 262 & 3,553 & 0,98 & \multirow{2}{*}{2,753} & \multirow{2}{*}{0,006} \\
\hline & İstemeden & 119 & 3,243 & 1,08 & & \\
\hline \multirow{2}{*}{$\begin{array}{l}\text { Turizmi bir kariyer yolu olarak seçmem- } \\
\text { den dolayı çok mutluyum }\end{array}$} & İsteyerek & 262 & 3,484 & 1,07 & \multirow{2}{*}{5,799} & \multirow{2}{*}{0,000} \\
\hline & İstemeden & 119 & 2,806 & 1,02 & & \\
\hline \multirow{2}{*}{$\begin{array}{l}\text { Turizmden başka bir alanda çalışmayı dü- } \\
\text { şünemem }\end{array}$} & İsteyerek & 262 & 3,087 & 1,26 & \multirow{2}{*}{4,142} & \multirow{2}{*}{0,000} \\
\hline & İstemeden & 119 & 2,521 & 1,18 & & \\
\hline Başka bir meslek seçme imkânım olsa, & İsteyerek & 262 & 3,137 & 1,31 & & 0,000 \\
\hline yine turizmi seçerdim. & İstemeden & 119 & 2,453 & 1,20 & 817 & \\
\hline
\end{tabular}

"Turizmde düzensiz ve uzun çalışma saatleri vardır" ve "Turizm çalışanları eğitilmiş iş gücüne yönelik önyargılı davranmaktadır" şeklindeki turizm çalışma hayatıyla ilişkili olumsuz yargıya sahip ifadelerinde de isteyerek gelenlerin istemeden gelenlere göre ortalamalarının yüksek olduğu görülmektedir. Bunun sebebi olarak isteyerek gelenlerin sektöre ilişkin çalışma koşullarını daha iyi bildikleri ancak buna rağmen genel turizm sektörüne ilişkin olumlu bir algıya sahip oldukları ve bu alanda çalışma konusunda daha istekli ve kararlı oldukları söylenebilir.

Denizli Sosyal Bilimler Meslek Yüksekokulu'nda mevcut iki turizm bölümü arasında mesleki algı konusunda anlamlı bir farklılık olup olmad1ğına ilişkin yapılan analiz sonuçları Tablo 7'de verilmiştir. Analiz sonuçların da Otel Lokanta İkram Hizmetleri bölümü ile Seyahat Turizm ve Ĕglence Hizmetleri bölümleri arasında yedi ifadede farklılık olduğu görülmüştür. 
Tablo 7: Bölümlere göre öğrencilerin mesleki algı durumu

\begin{tabular}{|c|c|c|c|c|c|c|}
\hline İfade & $\begin{array}{l}\text { Bö- } \\
\text { lüm }\end{array}$ & $\mathrm{N}$ & Ort. & Std.Sapm & $\mathrm{t}$ & $\begin{array}{l}\text { Sig }(2 \\
\text { tailed })\end{array}$ \\
\hline \multirow{2}{*}{$\begin{array}{l}\text { Turizm endüstrisinde çalışmak } \\
\text { ilgi çekicidir }\end{array}$} & OLİH & 204 & 3,553 & 1,11507 & \multirow{2}{*}{$-3,637$} & \multirow{2}{*}{0,000} \\
\hline & STEH & 178 & 3,915 & 0,82248 & & \\
\hline \multirow{2}{*}{$\begin{array}{l}\text { Daha fazla eğitim firsatları su- } \\
\text { nan bir meslektir }\end{array}$} & OLİH & 204 & 3,696 & 1,01019 & \multirow{2}{*}{2,947} & \multirow{2}{*}{0,003} \\
\hline & STEH & 178 & 3,376 & 1,10923 & & \\
\hline \multirow{2}{*}{$\begin{array}{l}\text { Her yerde iş bulma imkânı sun- } \\
\text { maktadır }\end{array}$} & OLIH & 204 & 3,676 & 1,12001 & \multirow{2}{*}{4,835} & \multirow{2}{*}{0,000} \\
\hline & STEH & 178 & 3,129 & 1,08411 & & \\
\hline \multirow{2}{*}{$\begin{array}{l}\text { Turizm endüstrisinde terfi ola- } \\
\text { nakları memnun edicidir }\end{array}$} & OLİH & 204 & 3,848 & 0,87744 & \multirow{2}{*}{3,484} & \multirow{2}{*}{0,001} \\
\hline & STEH & 178 & 3,528 & 0,91553 & & \\
\hline \multirow[t]{2}{*}{ Sorumluluk veren bir meslektir. } & OLİH & 204 & 3,995 & 0,97505 & \multirow{2}{*}{2,302} & \multirow{2}{*}{0,022} \\
\hline & STEH & 178 & 3,769 & 0,93142 & & \\
\hline \multirow{2}{*}{$\begin{array}{l}\text { Turizm endüstrisi kırılgan bir } \\
\text { yapı göstermektedir }\end{array}$} & OLİH & 204 & 3,593 & 0,87446 & \multirow{2}{*}{2,028} & \multirow{2}{*}{0,043} \\
\hline & STEH & 178 & 3,410 & 0,88637 & & \\
\hline \multirow{2}{*}{$\begin{array}{l}\text { Çalışanların eğitim seviyesi ge- } \\
\text { nelde düşüktür }\end{array}$} & OLİH & 204 & 3,470 & 1,20513 & \multirow{2}{*}{2,141} & \multirow{2}{*}{0,033} \\
\hline & STEH & 178 & 3,213 & 1,12969 & & \\
\hline
\end{tabular}

Tablo 7 incelendiğinde seyahat bölümü öğrencilerinin sektörü daha ilgi çekici bulduğu, görülmektedir. Bunun sebebi seyahat sektörünün daha dinamik bir yapıda olması ve daha esnek çalışma şartlarına sahip olması nedeniyle olabilir. Sektörün sunduğu eğitim fırsatlarını otel bölümü öğrencilerinin daha fazla bulduğu ancak sektörde çalışanların eğitim seviyelerinin de daha düşük olduğunu düşündükleri görülmektedir. İş fırsatlarının daha fazla olduğu ve terfi imkânlarının memnun edici düzeyde olduğu yönündeki ifadelere otel öğrencilerinin daha yüksek düzeyde katılımı sektör içinde konaklama işletmelerini ve yiyecek içecek işletmelerinin daha ağırlıklı olması ve iş ilanlarının daha yoğun olarak çeşitli mecralarda yer alması sebebiyle olduğu düşünülmektedir. "Turizm endüstrisi kırılgan bir yapı göstermektedir" ifadesine her iki grubunda yüksek katılım göstermesi sektörün özellikle son yıllarda yaşamış olduğu krizlere bağlanabilir.

Tablo 8: Mezun oldukları liseye göre öğrencilerin mesleki algı durumu

\begin{tabular}{|c|c|c|c|c|c|c|c|c|}
\hline & Gruplar & ort & Ss & & KT & $\mathrm{KO}$ & $F$ & $\mathrm{p}$ \\
\hline \multirow{6}{*}{$\begin{array}{l}\text { 2.Turizm endüstri- } \\
\text { sinde çalışacak ol- } \\
\text { maktan mutluyum }\end{array}$} & Normal & 3,394 & 0,974 & G.Ara & 8,287 & 4.144 & \multirow{3}{*}{3,639} & \multirow{3}{*}{0,027} \\
\hline & Turizm & 3,660 & 1,123 & G.İçi & 431,577 & 1,139 & & \\
\hline & Meslek & 3,308 & 1,090 & Toplam & 439,864 & & & \\
\hline & Toplam & 3,434 & 1,074 & & & & & \\
\hline & Normal & 3,377 & 0,999 & G.Ara & 18,202 & 9,101 & \multirow{2}{*}{7,293} & \multirow{2}{*}{0,001} \\
\hline & Turizm & 3,752 & 1,163 & G.İçi & 472,942 & 1,248 & & \\
\hline
\end{tabular}




\begin{tabular}{|c|c|c|c|c|c|c|c|c|}
\hline \multirow{2}{*}{$\begin{array}{l}\text { 6.Her yerde iş } \\
\text { bulma imkânı sun- } \\
\text { maktadır }\end{array}$} & Meslek & 3,226 & 1,163 & Toplam & 491,144 & & & \\
\hline & Toplam & 3,421 & 1,135 & & & & & \\
\hline \multirow{4}{*}{$\begin{array}{l}\text { 21.Turizm işletme- } \\
\text { lerinde daha çok } \\
\text { otokratik yöneticiler } \\
\text { çalışmaktadır }\end{array}$} & Normal & 3,201 & 0,932 & G.Ara & 8,646 & 4,323 & \multirow{3}{*}{4,794} & \multirow{3}{*}{0,009} \\
\hline & Turizm & 3,587 & 0,964 & G.İçi & 341,775 & 0,902 & & \\
\hline & Meslek & 3,327 & 0,951 & Toplam & 350421 & & & \\
\hline & Toplam & 3,363 & 0,959 & & & & & \\
\hline \multirow{4}{*}{$\begin{array}{l}\text { 24.Eğitimsiz insan- } \\
\text { lar önemli pozis- } \\
\text { yonlarda görev ala- } \\
\text { bilmektedir }\end{array}$} & Normal & 3,780 & 1,188 & G.Ara & 12,815 & 6,408 & \multirow{3}{*}{4,196} & \multirow{3}{*}{0,016} \\
\hline & Turizm & 3,816 & 1,225 & G.İçi & 578,766 & 1,527 & & \\
\hline & Meslek & 3,427 & 1,275 & Toplam & 591,581 & & & \\
\hline & Toplam & 3,644 & 1,246 & & & & & \\
\hline \multirow{4}{*}{$\begin{array}{l}\text { 27.Turizmde işgö- } \\
\text { ren hakları yeterli } \\
\text { seviyede gelişeme- } \\
\text { miştir }\end{array}$} & Normal & 3,403 & 1,094 & G.Ara & 7,960 & 3,980 & \multirow{3}{*}{3,136} & \multirow{3}{*}{0,045} \\
\hline & Turizm & 3,633 & 1,111 & G.İçi & 481,024 & 1,269 & & \\
\hline & Meslek & 3,283 & 1,159 & Toplam & 488,984 & & & \\
\hline & Toplam & 3,418 & 1,132 & & & & & \\
\hline \multirow{4}{*}{$\begin{array}{l}\text { 41.Turizm işletme- } \\
\text { ciliği eğitimi almam } \\
\text { kariyer gelişimimde } \\
\text { doğru bir karardır }\end{array}$} & Normal & 3,350 & 0,977 & G.Ara & 8,146 & 4,073 & \multirow{3}{*}{3,717} & \multirow{3}{*}{0,025} \\
\hline & Turizm & 3,715 & 1,106 & G.İçi & 415,331 & 1,096 & & \\
\hline & Meslek & 3,440 & 1,052 & Toplam & 423,476 & & & \\
\hline & Toplam & 3,492 & 1,054 & & & & & \\
\hline \multirow{4}{*}{$\begin{array}{l}\text { 44.Turizmden başka } \\
\text { bir alanda çalışmayı } \\
\text { düşünemem }\end{array}$} & Normal & 3,043 & 1,084 & G.Ara & 15,781 & 7,891 & \multirow{3}{*}{6,707} & \multirow{3}{*}{0,001} \\
\hline & Turizm & 3,568 & 1,100 & G.İçi & 445,905 & 1,177 & & \\
\hline & Meslek & 3,232 & 1,074 & Toplam & 461,686 & & & \\
\hline & Toplam & 3,272 & 1,100 & & & & & \\
\hline \multirow{4}{*}{$\begin{array}{l}\text { 45.Başka bir meslek } \\
\text { seçme imkânım } \\
\text { olsa, yine turizmi } \\
\text { seçerdim. }\end{array}$} & Normal & 2,684 & 1,177 & G.Ara & 14,795 & 7,398 & \multirow{3}{*}{4,706} & \multirow{3}{*}{0,010} \\
\hline & Turizm & 3,192 & 1,343 & G.İçi & 595,812 & 1,572 & & \\
\hline & Meslek & 2,867 & 1,243 & Toplam & 610,607 & & & \\
\hline & Toplam & 2,905 & 1,265 & & & & & \\
\hline
\end{tabular}

N=Normal Lise:114, Meslek Lisesi:159, Turizm Lisesi:109

Sd= G.Arası: 2, G. İçi: 379, Toplam: 381

Turizm öğrencilerinin mezun oldukları lisenin onların turizm mesleğine ilişkin algılarında bir fark oluşturup oluşturmadığının belirlenmesine yönelik olarak Anova analizi uygulanmıştır. Anova analizinde homojen dağılan ifadeler için Tukey testi, homojen dağılmayan ifadeler için Tamhane's T2 testi sonuçlarına bakılmış ve homojen dağılmayan ifadelerde anlamlı fark olmadığı görülmüştür. Homojen dağılan ifadelerden anlamlı fark bulunan ifadelerin analiz sonuçları Tablo 8' de verilmiştir.

Öğrencilerin mezun oldukları liseye göre göre turizm mesleğine alg1larındaki farklılıkları incelemek için Tablo 8'e bakıldığında sekiz ifadeye katılım durumlarında anlamlı farklılıklar olduğu görülmektedir. Turizm lisesi çıkışlı öğrencilerin hem olumlu hem de olumsuz ifadelerde diğer liselerden mezun öğrencilere göre daha yüksek ortalamalarla farklılaştıkla- 
rının görüldüğü ifadeler içerik olarak turizm mesleğinin yapısı ve bu meslekle ilgili öğrencilerinin beklentilerinin sonuçlarına ilişkin ifadelerdir. Turizm lisesi çıkışlı öğrencilerin turizm mesleğini genel olarak diğerlerine göre yakından tanımaları onların beklentilerinin diğerlerine göre daha nesnel ve gerçekçi bir düzeyde oluşmasını sağlamış olmalıdır. Ayrıca muhtemeldir ki lise sürecinde turizmle ilgili karşılaştıkları olumlu ve olumsuz pek çok duruma rağmen bu mesleğe devam etmeyi isteyerek bu bölümleri tercih etmişlerdir. Bu sebeple "turizm endüstrisinde çalışacak olmaktan mutluyum, her yerde iş bulma imkânı sunmaktadır, turizm işletmeciliği eğitimi almam kariyer gelişimimde doğru bir karardır, turizmden başka bir alanda çalışmayı düşünemem ve başka bir meslek seçme imkânım olsa, yine turizmi seçerdim" ifadeleri ortalamaları diğerlerinden yüksek gerçekleşmiştir. Olumsuz olarak ankette yer alan "turizm işletmeleri içerisinde daha çok otokratik yöneticiler çalışmaktadır, eğitimsiz insanlar önemli pozisyonlarda görev alabilmektedir ve turizmde işgören hakları yeterli seviyede gelişememiştir" ifadelerine katılım ortalamaları turizm lisesi öğrencilerinin yönetici davranışları ve iş koşullarına yönelik algılarının sektörde staj döneminde karşılaştıkları olumsuzluklarla ilişkili olduğu düşünülmektedir.

\section{Sonuç}

Araştırma sonucunda, turizm öğrencilerinin turizm mesleğine yönelik alg1 farklılıkları incelenmiş ve öğrencilerin en yüksek düzeyde katılım gösterdiği ifadenin "farklı kültürlerden ve milletlerden insanlarla tanışmalarının onları mutlu ettiği ve turizm mesleğine olumlu algıya katkı sağladığı"; en düşük düzeyde katılım gösterdiği "kendini geliştirme imkânları azdır" ifadesi ters çevrilerek kodlanmış ve dolayısıyla turizm sektöründe kendi gelişim imkanlarını olumlu gördükleri anlaşılmaktadır. Ancak öğrencilerin çalışma alanı olarak turizmi seçmelerine ilişkin "Turizmden başka bir alanda çalışmayı düşünemem" ve "Başka bir meslek seçme imkânım olsa, yine turizmi seçerdim" ifadelerine katılım oranlarının düşük olması öğrencilerin turizm alanında çalışmaya sıcak bakmadıkları ve başka sektörlerde ortaya çıkabilecek firsatlarda sektör değiştirmeyi düşünecekleri anlamına gelebilir. 
Cinsiyet değişkenine göre anlamlı farklılık bulunan ifadenin ortaya koyduğu sonuç öğrencilerin sektöre yönelik algılarının istikrarsız ve kırılgan bir yapıda olduğu yönündedir. Genel olarak son yıllarda turizm sektöründe inişli çıkışlı dönemlerin yaşanması ve bunların medya kanallarında olumsuz şekilde yer almasının öğrencilerin bu yönde bir algı geliştirmesine sebep olduğu ifade edilebilir.

Turizm öğrencilerinin öğretim durumlarına göre, örgün öğretim ve ikinci öğretim öğrencilerinin mesleki algılamalarında "Turizmde işgören hakları yeterli seviyede gelişememiştir" ifadesinde anlamlı bir farklılık olduğu tespit edilmiştir. Örgün öğretim okuyan öğrenciler, işgören haklar1nın yeterince gelişmediği fikrine ikinci öğretim öğrencilerine göre daha fazla katılmaktadırlar. Ancak her iki grup ortalamalarının üçün üzerinde olması öğrencilerin ağırlıklı olarak bu fikre katıldığını da göstermektedir.

Okudukları sınıf açısından öğrencilerin meslek algısı incelendiğinde, birinci sınıfta okuyan öğrencilerin mesleğe ilişkin algılarının ikinci sınıfta okuyan öğrencilere göre daha olumlu olduğu görülmektedir. Bunun nedeni olarak Denizli Sosyal Bilimler Meslek Yüksekokulu'ndaki öğrencilerin birinci sınıf sonunda stajlarını yapmaları ve staj süresince işyerleri, iş koşulları ve sosyal çevre konusunda bilgi edinmelerinin onların mesleğe bakışlarında belirli ölçüde olumsuz etki ettiği söylenebilir.

Öğrencilerin mezun oldukları liseye göre turizm mesleğine ilişkin algıları incelendiğinde, turizm lisesi çıkışlı öğrencilerin hem olumlu hem de olumsuz ifadelerde diğer liselerden mezun öğrencilere göre daha yüksek ortalamalarla farklılaştıkları görülmektedir. Bu ifadeler, içerik olarak turizm mesleğinin yapısı ve bu meslekle ilgili öğrencilerinin beklentilerinin sonuçlarına ilişkin ifadelerdir. Turizm lisesi çıkışlı öğrencilerin turizm mesleğini genel olarak diğerlerine göre yakından tanımaları, onların beklentilerinin diğerlerine göre daha nesnel ve gerçekçi bir düzeyde oluşmasını sağlamış olmalıdır. Ayrıca muhtemeldir ki lise sürecinde turizmle ilgili karşılaştıkları olumlu ve olumsuz pek çok duruma rağmen bu mesleğe devam etmeyi isteyerek bu bölümleri tercih etmişlerdir. Bu sebeple "turizm endüstrisinde çalışacak olmaktan mutluyum, her yerde iş bulma imkânı sunmaktadır, turizm işletmeciliği eğitimi almam kariyer gelişimimde doğru bir karardır, turizmden başka bir alanda çalışmayı düşünemem ve başka bir meslek seçme imkânım olsa, yine turizmi seçerdim" ifadeleri ortalamaları diğerlerinden yüksek gerçekleşmiştir. Olumsuz olarak 
ankette yer alan "turizm işletmeleri içerisinde daha çok otokratik yöneticiler çalışmaktadır, eğitimsiz insanlar önemli pozisyonlarda görev alabilmektedir ve turizmde işgören hakları yeterli seviyede gelişememiştir" ifadelerine katılım ortalamaları turizm lisesi öğrencilerinin yönetici davranışları ve iş koşullarına yönelik algılarının sektörde staj döneminde karşılaştıkları olumsuzluklarla ilişkili olduğu düşünülmektedir.

Bölümlere göre öğrencilerin meslek algısı incelendiğinde, seyahat ve turizm bölümü öğrencilerinin mesleği daha ilgi çekici bulmalarının, seyahat işletmelerinin dinamik yapısından kaynaklı olduğu söylenebilir. Turizm ve otelcilik bölümü öğrencilerinin iş fırsatları, eğitim imkanları, terfi olanakları ve işe ait sorumlulukla ilgili ifadelere daha yüksek katılım göstermesi, sektörde konaklama işletmelerinin daha ağırlıklı olması ve daha kurumsal bir yapıya sahip olmaları sebebiyle olduğu ifade edilebilir. Ancak turizm ve otelcilik öğrencileri, çalışanların eğitim seviyesinin genelde düşük olduğu ifadesine daha çok katılmaktadır.

Turizm bölümlerine isteyerek gelen öğrencilerin turizme yönelik olumlu ifadelerde istemeyerek gelenlere göre belirgin bir şekilde farklılaştıkları ve daha yüksek ortalamalara sahip oldukları görülmektedir. "Turizmde düzensiz ve uzun çalışma saatleri vardır" ve "Turizm çalışanları eğitilmiş iş gücüne yönelik önyargılı davranmaktadır" şeklindeki turizm çalışma hayatıyla ilişkili olumsuz yargıya sahip ifadelerinde de, isteyerek gelenlerin istemeden gelenlere göre ortalamalarının yüksek olduğu görülmektedir. Bunun sebebi olarak da isteyerek gelenlerin sektöre ilişkin çalışma koşullarını daha iyi bildikleri ancak buna rağmen turizm sektörüne ilişkin olumlu bir algıya sahip oldukları söylenebilir.

$\mathrm{Bu}$ çalışma ile ortaya konulan sonuçlar çerçevesinde öğrencilerin turizm sektörü algılarının çeşitli değişkenlere göre farklılaştı̆̆ı, ancak genel olarak sektörün yapısını, çalışma koşularını, işletmelerdeki çalışan profillerini ve yönetici davranışlarını bilen ya da bilmeyen tüm öğrencilerin sektöre karşı algılarının olumsuz olduğu görülmektedir. Bu olumsuz genel algıya rağmen öğrencilerin bir kısmı turizm sektöründe çalışma ve kariyer hedeflerini bu alanda oluşturmaları bu sektörün sunduğu fırsatlarında öğrenciler tarafından cazip olarak görüldüğünü göstermektedir. Turizmde kalitenin ve turizm işletmelerinde verimliliğin çalışan kalitesi ve verimliliği ile yakından ilişkili olduğu bu yüzden eğitimli işgücünü bu sektörde tumanın önemli olduğu göz önünde bulundurulduğunda bu 
genç insanların sektörden soğutulmaması hem üniversitelerin hem de sektörde yer alan işletmelerin sorumluluğundadır. Bu yüzden bu çalışmada olumsuz olarak algılandığı görülen konuların incelenerek gerçekten algılandığı gibi olumsuz mu olduğu yoksa çeşitli ön yarg1 ve duyumlardan mı kaynaklı olduğu tespit edilmeli ve daha yolun başında bunlar düzeltilmeye çalışılmalıdır. 


\section{EXTENDED ABSTRACT}

\section{The Occupational Perceptions of The Associate Degree Tourism Students to The Sector: Pamukkale University Case}

*

Ahmet Çetin - Seher Ceylan - Nuray Selma Özdipçiner

Pamukkale University

Tourism is an extremely important sector for all countries today. In order to achieve maximum profit from this sector, it is necessary to provide quality and to ensure guest satisfaction. The first step of providing quality in service is reintegrate qualified and educated workforce into the sector. The training of this workforce is also possible with effective tourism education. In our country, tourism education is offered at both secondary and higher education levels and it is expected that the individuals receiving this training will also work in the tourism sector. At the end of the education period of the students who aim the working in tourism, how they perceive their career opportunities and how they see the sector are important to be part of this profession. Unfortunately, the research shows that a significant portion of the students receiving tourism education do not want to work in the sector or have acquired a profession in other areas than tourism. In this context, it is important to consider how tourism student's perceptions of tourism on working conditions and their point of view to the sector.

With this research, it is aimed to reveal the perception differences of Tourism, Hospitality and Travel Tourism and Entertainment Services students who are studying at the associate degree level. Fort his purpose, a questionnaire was applied for the pre-graduate students who received tourism education in Pamukkale University Denizli Social Sciences Vocational School in the spring term of 2017-2018 academic year. The questionnaire, which was used as a data collection tool, was adapted by Karaman (2008) to measure the professional perception of teachers, and adapted by Y1lmaz, Şen and Demirkaya (2014) to measure the professional perception 
of nurses and midwives and adapted for the cooks by Yilmaz and Tanr1verdi (2017). The scale consisted of 46 expressions and each expression was evaluated by using 5-point Likert scale. The Cronbach Alpha coefficient of the scale was found to be 0.916 . In this respect, the scales were accepted as reliable (Hair et al. 1995, p.118). Of the 420 questionnaires obtained from the study, 382 were valid. As a result of the research, differences between the demographic characteristics of the tourism students and their perceptions about the profession were determined. The result of the expression which has a meaningful difference according to the gender variable is that students' perceptions about the sector are in an unstable and fragile structure. When the perceptions of the students are examined in terms of the class they study, it is seen that first-year students' perceptions about the profession are more positive than the second grade students. When the differences of perception according to the high school graduates are examined, it is seen that the students who are from high school of tourism have higher averages in both positive and negative expressions than the students who graduated from other high schools. When the students' perception of profession according to departments is examined, it is revealed that the students of the travel and tourism department find the profession more interesting. It can be stated that the students of the Tourism and Hospitality Department are more likely to participate in the job opportunities, training opportunities, promotion opportunities and expressions related to the job, because the accommodation companies in the sector are more weighted and have a more institutional structure. As a result of the study, it was determined that students supported their development opportunities in the tourism sector positively, but they did not favor working in the field of tourism and supported expressions which meant that they would consider changing the sector in opportunities that might arise in other sectors.

In this study, it is observed that students' perceptions of tourism differ according to various variables, but in general the perceptions of all students are negative for the sector who know or don't know, about the working conditions of tourism, the employee profiles, manager behaviors and the structure of the sector. Despite this negative general perception, it is seen that some of the students aim to work in the tourism sector and create 
their careers in this field. This situation shows that the opportunities offered by the sector are considered attractive by the students despite some negative perceptions. Considering the fact that the quality of tourism is closely related to the quality of the employees, so the fact that, educated workforce is important in tourism, hence both the universities and the companies have responsibilities to not disincline these young people from the sector. Therefore, it should be determined by examining the issues that are perceived as negative in this study, whether it is really perceived as negative or due to various prejudices and sensations and they should be corrected on the bottom rung.

\section{Kaynakça / References}

Aslan, Z., Ünüvar, Ş. ve Başoda, A. (2012). Turizm eğitimi alan öğrencilerin kişilik özelliklerinin belirlenmesi ve turizm sektörüne uyumu açısından değerlendirilmesi. Anatolia: Turizm Araştırmaları Dergisi, 23 (2), 203-219.

Avcı, N. (2011). Turizm eğitimi alan lisans öğrencilerinin iş değerleri: Çeşme Turizm ve Otelcilik Yüksekokulu örneği. Anatolia: Turizm Araştırmaları Dergisi, 22 (1), 7-18.

Bahçelerli, N. M., ve Sucuoğlu, E., (2015). Undergraduate tourism students' opinions regarding the work conditions in the tourism industry. Procedia Economics and Finance, 26, 1130-1135.

Baltac1, F., Üngüren, E., Avsallı, H. ve Demirel, O. N. (2012). Turizm eğitimi alan öğrencilerin eğitim memnuniyetlerinin ve geleceğe yönelik bakış açıların belirlemesine yönelik bir araştırma, Uluslararası Alanya İşletme Fakültesi Dergisi, 4(1), 17-25.

Cömert, M. (2014). Turizm eğitimi alan öğrencilerin sektörde çalışmak istedikleri alanlar ve sektördeki istihdamda cinsiyet ayrımcilığılya ilgili düşünceleri. Gazi Üniversitesi Turizm Fakültesi Dergisi, 1, 50-6.

Çarıkçı, İ. H. ve Morçin, S. E., (2014). Önlisans turizm öğrencilerinin kariyer değerleri: Sarıkamış örneği, Elektronik Mesleki Gelişim ve Araştırma Dergisi (EJOIR), 2 (Özel Sayı), 67-81.

Çimen, H. (2008). Turizm lisans öğrencilerinin mesleki yönelimleri: Akçakoca turizm işletmeciliği ve otelcilik yüksekokulu örneği, $A n$ atolia: Turizm Araştırmaları Dergisi, 19 (2), 194-202. 
Duman, T., Tepeci, M. ve Unur, K. (2006). Mersin'de yükseköğretim ve orta öğretim düzeyinde turizm eğitimi almakta olan öğrencilerin sektörün çalışma koşullarını algılamaları ve sektörde çalışma isteklerinin karşılaştırmalı analizi. Anatolia: Turizm Araştırmaları Dergisi, 17(1), 51-69.

Grobelna, A. (2017). The perception of job-related motivators when choosing a career in the tourism and hospitality industry-A comparative study between Polish and Spanish students. International Journal of Management and Economics, 53(2), 84-106.

Hair, J.F., Anderson, R.E., Tahtam, R.L. ve Black, W.C. (1995). Multivariate data analysis with readings. New Jersey: Prentice Hall Inc.

Karaman, N. (2008). Öğretmenlerin mesleklerini algılama biçimleri ve gelecekten beklentileri nelerdir? Yüksek Lisans Tezi, Trakya Üniversitesi, Sosyal Bilimler Enstitüsü, Edirne.

Kim, H. B. ve Park, E. J. (2013). The Role Of Social Experience İn Undergraduates' Career Perceptions Through İnternship. Journal of Hospitality, Leisure, Sport E Tourism Education 12, 70-78.

Köşker, H. ve Unur, K. (2017). Turizm lisans öğrencilerinin turizm sektöründe çalışma eğilimleri üzerine bir araştırma, Seyahat ve Otel İşletmeciliği Dergisi, 14(2), 128-141.

Lu, T. and Adler, H. (2009). Career goals and expectations of hospitality and tourism students in China, Journal of Teaching in Travel \& Tourism, 9, 63-80.

Olcay, A. ve Çelik, Z. (2010). Turizm ve otel işletmeciliği programında öğrenim gören öğrencilerin otelcilik mesleğine ilişkin algıları, $G a-$ ziantep Üniversitesi Sosyal Bilimler Dergisi, 9(2), 279-301.

Orhan, A (2015). Türkiye'de lisans düzeyinde turizm eğitimi alan öğrencilerin turizm sektörü ile ilgili algılarının çalışma niyetleri üzerindeki etkisinin belirlenmesi, Yüksek Lisans Tezi, Osmangazi Üniversitesi Sosyal Bilimler Enstitüsü, Eskişehir.

Sarışık, M. (2007). Turizm sektöründe meslek sahibi olmaya yönelten etkenler: Meslek yüksekokulu öğrencilerine yönelik bir çalışma, $A n-$ atolia: Turizm Araştırmaları Dergisi, 18 (2), 143-160. 
Solmaz, S. A., Aksoy, Ö. Şengül, S. ve Sarışık, M. (2014). Üniversite öğrencilerinin girişimci kişilik özelliklerinin belirlenmesi: Turizm lisans ve ön lisans öğrencileri üzerine bir alan araştırması. KMÜ Sosyal ve Ekonomik Araştırmalar Dergisi, 16 (26), 41-55.

Tekin, Ö. A. ve Deniz, İ. (2015). Turizm öğrencilerinin yiyecek ve içecek departmanına yönelik tutumları: Üniversite öğrencileri üzerine bir inceleme. Elektronik Sosyal Bilimler Dergisi, 14(55), 178-197.

Üngüren, E. ve Ehtiyar, R. (2009). Türk Ve Alman öğrencilerin umutsuzluk düzeylerinin karşılaştırılması ve umutsuzluk düzeylerini etkileyen faktörlerin belirlenmesi: Turizm eğitimi alan öğrenciler üzerinde bir araştırma. Journal of Yasar University, 4(14), 2093-2127.

Üzümcü, T. P., Alyakut, Ö. Ve Günsel, A. (2015). Turizm eğitimi alan öğrencilerin, mesleğin geleceğine ilişkin bakış açıları. Balıkesir Üniversitesi Sosyal Bilimler Enstitüsü Dergisi, 18(33), 179-199.

Wan, Y. K. P., Wong, I. A. ve Kong, W. H., (2014). Student career prospect and industry commitment: The roles of industry attitude, perceived social status, and salary expectations. Tourism Management, $40,1-14$

Wijesundara, W.G.S.R. (2015). An evaluation of graduates:Perception on employment in tourism and hospitality industry. Tourism, Leisure and Global Change, 2, 172-182.

Yayla, Ö., Silik, C. E. ve Dülger, A. S., (2017). Turizm lisans ve önlisans eğitiminde 2017 yılı sayısal değerlendirmeler. Journal of Tourism and Şastronomy Studies, 5(4), 47-58.

Yılmaz, A. ve Tanrıverdi, H. (2017). Aşçıların meslek uyumu ve meslek algısı düzeyleri üzerine bir araştırma. Karabük Üniversitesi Sosyal Bilimler Enstitüsü Dergisi, 7 (2), 621- 639

Yılmaz, T. F., Şen, T. H. ve Demirkaya, F. (2014). Hemşirelerin ve ebelerin mesleklerini algılama biçimleri ve gelecekten beklentileri. Sağ lık ve Hemşirelik Yönetimi Dergisi, 1(3), 130-139.

Zengin, B. ve Kırmızı, A. (2017). Turizm eğitimi alan öğrencilerin uygulama eğitiminde karşılaştıkları sorunları ve çözüm önerileri: Gazi Üniversitesi örneği. Akademik Sosyal Araştırmalar Dergisi, 5(48), 564-582. 
Zubaidah, M. A. T., Norhafizah, B., Norhidayah, M. W., Anderson, A. N., Najua, M. A., Norfadzliana, G, ve Siti, A. A. T., (2016). Graduates:Perception on the factors affecting commitment to pursue career in the hospitality industry. Procedia Social and Behavioral Sciences, 224, 416-420.

\section{Kaynakça Bilgisi / Citation Information}

Çetin, A., Ceylan, S. ve Özdipçiner, N. S. (2019). Turizm eğitimi alan önlisans öğrencilerinin sektöre yönelik meslek algıları: Pamukkale Üniversitesi örneği. OPUS-Uluslararası Toplum Araştırmaları Dergisi , 11(18), 1970-1995. DOI: 10.26466/opus.554480 